
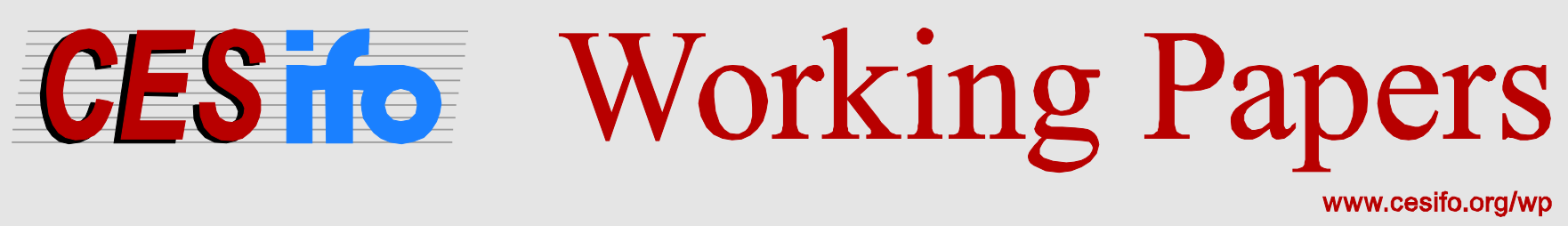

\title{
Indian Entrepreneurial Success in the United States, Canada and the United Kingdom
}

\author{
Robert W. Fairlie \\ Harry Krashinsky \\ Julie Zissimopoulos \\ Krishna B. Kumar
}

CESIFO WORKING PAPER NO. 4510

CATEGORY 4: LABOUR MARKETS

DECEMBER 2013

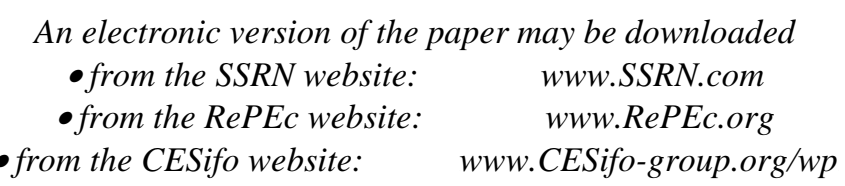




\title{
Indian Entrepreneurial Success in the United States, Canada and the United Kingdom
}

\begin{abstract}
Indian immigrants in the United States and other wealthy countries are successful in entrepreneurship. Using Census data from the three largest developed countries receiving Indian immigrants in the world -- the United States, United Kingdom and Canada -- we examine the performance of Indian entrepreneurs and explanations for their success. We find that business income of Indian entrepreneurs in the United States is substantially higher than the national average and is higher than any other immigrant group. Approximately half of the average difference in income between Indian entrepreneurs and the national average is explained by their high levels of education while industry differences explain an additional 10 percent. In Canada, Indian entrepreneurs have average earnings slightly below the national average but they are more likely to hire employees, as are their counterparts in the United States and United Kingdom. The Indian educational advantage is smaller in Canada and the United Kingdom contributing less to their entrepreneurial success.
\end{abstract}

JEL-Code: L260, J150.

Keywords: entrepreneurship, immigration, Indian migrants.

\author{
Robert W. Fairlie \\ University of California / Santa Cruz \\ USA \\ rfairlie@ucsc.edu \\ Julie Zissimopoulos \\ RAND \\ Santa Monica / California / USA \\ ziss@rand.org
}

\author{
Harry Krashinsky \\ University of Toronto \\ Ontario / Canada \\ harry.krashinsky@utoronto.ca \\ Krishna B. Kumar \\ RAND \\ Santa Monica / California / USA \\ kumar@rand.org
}

December 2009

We would like to thank Garth Frazer, William Kerr, Josh Lerner, Anna Paulson, Solomon Polacheck, Antoinette Shoar, and seminar participants at the AEA Meetings, the University of Wisconsin, and the World Bank-Kauffman Conference on Entrepreneurship and Growth for comments and suggestions. We would also like to thank Miranda Smith and Joanna Carroll for research assistance. We thank the Kauffman-RAND Institute for Entrepreneurship Public Policy and the Kauffman Foundation for partial funding. 


\section{Introduction}

Entrepreneurship is associated with economic growth. Entrepreneurs contribute to economic growth by creating new industries, increasing productivity through competition, identifying viable new technologies, and working efficiently and intensively. Based on cross-country data, van Stel, Carree, and Thurik (2005) find this relationship between entrepreneurship and growth is positive for developed countries but negative in developing countries speculating the negative association may in part be due to low levels of human capital of entrepreneurs in developing countries.

India is one of the developing countries included in the van Stel et al (2005) study and is interesting because Indian immigrants in the United States are highly successful in entrepreneurship. The average net business income of Indian entrepreneurs is $\$ 84,080$, significantly higher than the national average of $\$ 52,086$. The success of Indian entrepreneurs in the United States is particularly striking, given India’s low per capita income -- only $\$ 2,644$ adjusted for purchasing power parity. Immigrants from countries where the per capita income is much higher than in India, including Taiwan, Korea, Greece, Germany, and England, have substantially lower entrepreneurial earnings than Indian entrepreneurs in the United States. In fact, Indian immigrants have the highest average net business income of all immigrant groups in the United States. The evidence on Indian immigrants’ entrepreneurial achievement in other wealthy countries such as the United Kingdom and Canada is less conclusive, but also suggestive of success. ${ }^{1}$ In both countries, Indian entrepreneurs are more likely to hire employees than the national average.

\footnotetext{
${ }^{1}$ Examining the success of Indian entrepreneurs across a range of industrialized countries could shed light on country-specific factors that are responsible for their performance beyond the traits of entrepreneurs themselves.
} 
More than one million Indians have migrated to the United States making it the largest receiving country in the world. The United Kingdom, with half a million Indian immigrants, and Canada, with roughly a third of a million, are the next two largest receiving countries in the developed world. While many of these immigrants seek employment in established firms in the host nations, many also become entrepreneurs, especially in technology-laden fields. Twenty-five percent of engineering and technology companies started in the U.S. during the past decade were founded by immigrants many of whom are from India (Wadwha, et al. 2007). These firms had $\$ 52$ billion in sales and hired 450,000 workers in 2005. Previous research also indicates that immigrant entrepreneurs have made important contributions to high-tech areas such as Silicon Valley (Saxenian 1999, 2000). Engineers from China and Indian run roughly one quarter all technology businesses started in Silicon Valley.

In the context of the discussion surrounding the work of van Stel et al (2005), a systematic exploration of Indian entrepreneurs in developed countries would be a useful first step in understanding if human capital can explain much of this success, the contribution of immigrant groups to entrepreneurship and growth in developed countries, and the corresponding loss, if any, to the home countries. This is the step we take in this paper. Although previous research using data from various countries provides some evidence on the success of Indian entrepreneurs, a comprehensive analysis has not been previously performed (see Mar 2005, Fairlie and Robb 2008, Kalnins and Chung 2006, Clark and Drinkwater 2000, 2006, Li 2001, Ley 2006, Johnson 2000, and Singh 2004 for a few recent studies).

We take a broad geographical and industrial approach to examine the performance of Indian entrepreneurs. In particular, we use Census data from the United States, United 
Kingdom and Canada to provide the first analysis of entrepreneurship among Indian immigrants in the three largest receiving developed countries. ${ }^{2}$ The sample sizes for all three Censuses are extremely large and allow us to examine business performance among Indian entrepreneurs in the three countries. In fact, these are the only nationally representative micro-datasets with large enough samples sizes to conduct a focused analysis on Indian entrepreneurs.

Little research has attempted to identify the sources of the high returns to Indian entrepreneurship in the United States and other industrialized countries. Do observable characteristics explain their success, or is there a country-specific effect at work? One hypothesis, echoing the view of van Stel, Carree, and Thurik (2005), is that high levels of education contribute to the success of Indian entrepreneurs. That is, the exodus of highlyeducated workers or "Brain Drain" from India may be responsible for entrepreneurial success in these developed countries although surprisingly this question has not been studied in the previous literature. Another potential explanation is that Indian entrepreneurs concentrate in high earnings industries, which also has not been studied. We address these questions in the paper.

Using decomposition techniques, we find that education explains nearly half of the difference in business income between Indian entrepreneurs and U.S. born white entrepreneurs (which approximates the national average) and sectoral choice explains another one-fifth of the difference. Once other observable characteristics such as gender, age, and marital status are included, nearly three-quarters of the difference can be explained. In

\footnotetext{
${ }^{2}$ Fairlie, Zissimopoulos, and Krashinsky (2008) examine business ownership and performance patterns in the United States, Canada and United Kingdom for Asian immigrants, and Schuetze and Antecol (2006) provide a detailed comparison of immigrant business formation in the Australia, Canada and the United States. Neither study, however, focuses on Indian entrepreneurs.
} 
Canada, Indian entrepreneurs have average earnings slightly below the national average but they are more likely to hire employees, as are their counterparts in the United States and the United Kingdom. The Indian educational advantage is smaller in Canada and the United Kingdom partly contributing to lower relative entrepreneurial success in these countries. The results suggest that most of the Indian entrepreneurial success can be explained by observable differences that are a priori plausible rather than recourse to a country-specific effect.

The rest of this paper proceeds as follows. In the next section we discuss the data sources for the three countries. Section 3 presents descriptive statistics on the performance of Indian entrepreneurs in the United States, Canada, and the United Kingdom. In Section 4, we analyze the causes of Indian entrepreneurial success in each of the three countries using decomposition techniques. Section 5 concludes.

\section{Data}

For the analysis, we use the 2000 U.S. Census of Population Public Use Microdata (PUMS) 5-Percent Samples (14.1 million observations), the 2001 United Kingdom Census 3Percent Sample from the Individual Anonymised Records (1.6 million observations), and the 2001 Canada Census Public Use Microdata File (PUMF) of about 2.7 percent of the population (approximately 800,000 observations). The Census samples from each country are representative of the entire population in the country, resulting in representative samples of all immigrant groups residing in each country at the time of the surveys. Our analysis sample for the United Kingdom, however, includes only England and Wales. In all censuses, 
information on birth country, ethnicity and immigration status is provided and used to define Indian and other Asian immigrant groups. ${ }^{3}$

For all censuses we define business owners from the class of worker question for the main job activity in the survey week. In the United States the questions asked allow us to identify as self-employed business owners all owners of unincorporated, incorporated, employer and non-employer businesses although we cannot distinguish between the latter two. In Canada, the main job question allows us to identify as business owners all owners of unincorporated and incorporated businesses with and without paid help. ${ }^{4}$ In the United Kingdom, the main job question allows us to identify as business owners self-employed workers with employees and those without employees.

The U.S. and Canadian Censuses report business income allowing us to measure the performance of Indian and other businesses. In the U.K. Census, business income is not publicly available. We distinguish between employer businesses (which have employees) and non-employer businesses as an alternative measure of performance. The Canadian Census also allows for the identification of employer businesses.

For all countries, we restrict the samples to include individuals ages 25-64. We exclude young workers to identify completed schooling and older workers because of the complication with retirement decisions. ${ }^{5}$ We also exclude individuals who are not currently

\footnotetext{
${ }^{3}$ The Canadian pubic use data restrict the detail on exact country of birth so ethnicity and immigration status is primarily used to categorize Asian immigrants. In the U.K., India, Pakistan and Bangladesh together are identified as birth countries and 'Rest of Asia.' Thus ethnicity is also used here to categorize specific Asian immigrant groups. We did not include N. Ireland and Scotland because the ethnicity variable in the UK Census (DETHEW) applies only to England and Wales. ${ }^{4}$ The job reported was the one held in the survey week. Persons with two or more jobs in the reference week were asked to provide information for the job at which they worked the most hours. ${ }^{5}$ Zissimopoulos, Maestas and Karoly (2007) show self-employed workers in the United States and England retire at lower rates than wage and salary workers due to differential incentives from pension and health insurance systems.
} 
working and who do not report working at least 15 hours per week. ${ }^{6}$ Although sidebusinesses are already ruled out because of the focus on business ownership for the main job activity, these restrictions exclude all small-scale business activities. The additional exclusion of agricultural industries has little effect on estimates of Indian immigrant entrepreneurship, and thus we include these industries in all analyses.

Educational distributions are not perfectly comparable across the three countries because of differences in educational systems. To make comparisons across countries we focus on the percent of the prime-age workforce that has a college degree. In the U.K. Census, education is reported as highest qualification obtained and translated into one of five levels such that level 4 and 5 represent a college education or higher. ${ }^{7}$ Indians may obtain their education abroad or in the host country. Unfortunately, the Census data from all three countries do not provide evidence on where the education was obtained. However, since Indians who have graduated from the leading colleges are the ones more likely to emigrate, the loss of information on the source of education and therefore the quality of such education is not likely to be severe. ${ }^{8}$

\footnotetext{
${ }^{6}$ For the U.K. and Canada Censuses, hours per week refer to the survey week, whereas the U.S. Census only provides information on hours worked in the usual week worked over the previous year. Employment status, however, is determined for the survey week.

${ }^{7}$ Level 1 (low education) is held by 18.8 percent of the working age population, level 2 and 3 held by 18.2 and 6.3 percent of the working age population respectively, and level 4 and 5 (high, generally college and above) held by 22.7 percent of the working age population. In addition, 26.3 report no qualifications and 7.6 percent report other qualifications.

${ }^{8}$ Docquier and Marfouk (2005) report that India is third among the list of skilled emigration countries (behind the U.K. and the Philippines) as measured by emigration stocks. But, more pointedly, Agrawal, Kapur, and McHale (2008) note that while the overall tertiary emigration rate from India is about $4 \%$, rates from the elite Indian Institutes of Technology is much higher (31\% of the graduates from the Mumbai campus emigrated in the 1970 s when compared to $7.3 \%$ from all engineers).
} 


\section{Indian Entrepreneurs in the United States}

More than one million immigrants from India reside in the United States based on estimates from the 2000 Census. The only source countries with more immigrants in the United States are Mexico (9.3 million), the Philippines (1.5 million), and Germany (1.2 million). The rate of business ownership is not substantially higher among Indian immigrants than the national average. Estimates from the Census indicate that 10.9 percent of the Indian immigrant workforce owns a business compared with 10.1 percent of the total workforce in the United States (Fairlie, Zissimopoulos, and Krashinsky 2008). The rate of business ownership is the same as the rate for all Asian immigrants of 10.9 percent. The interesting difference between Indian immigrants and the national average is not in business ownership rates, but is in the relative success of these businesses. The businesses owned by Indian entrepreneurs are very successful on average when compared to all businesses and other Asian immigrant owned businesses.

Table 1 reports estimates of net business income by group in the United States. Indian entrepreneurs earn $\$ 84,080$ per year on average. This is roughly 60 percent higher than the national average income of business owners $(\$ 52,086) .{ }^{9}$ Indian entrepreneurs also earn more on average than all Asian immigrants combined. Combining all Asian immigrant groups average earnings are $\$ 54,208$. Removing Indian immigrants from the Asian immigrant total reduces the average level of earnings by another $\$ 5,500$.

More broadly, Indian entrepreneurs have the highest business income of all immigrant groups in the United States. Table 2 reports estimates for detailed immigrant groups. All source countries with at least 300 observations (representing roughly 6,000

\footnotetext{
${ }^{9}$ Median business income among Indian entrepreneurs is 40 percent higher than the median level for all entrepreneurs in the United States.
} 
actual businesses in the United States) are reported. Of the 44 groups listed, Indian

entrepreneurs have the highest average business income level. ${ }^{10}$ Indian entrepreneurs are more successful on average than entrepreneurs from wealthy countries such as Canada, the United Kingdom, Germany, the Netherlands, and Ireland. In most cases, Indian entrepreneurs earn $\$ 20,000$ more than these groups, which is remarkable given that the GDP per capita of India, even after adjusting for purchasing power parity, is less than one tenth of that of the European Union. Indian entrepreneurs are also by far the highest earning entrepreneurs from any country in Asia.

The finding of superior performance among Indian entrepreneurs is consistent with estimates from other data sources. The only other nationally representative dataset with information on owners' race and large enough sample sizes for examining the performance of Indian entrepreneurs is the Survey of Business Owners (SBO) and its earlier version the Characteristics of Business Owners (CBO). ${ }^{11}$ Estimates from the CBO and SBO provide evidence that Indian-owned businesses have higher profits and hire more employees than the average for all firms (Fairlie and Robb 2008). Indian firms are also substantially less likely to close than are all firms. ${ }^{12}$ The only exception is that Indian firms are found to have similar levels of total sales as the national average. Business-level data thus confirms the finding from individual-level data on the performance of Indian entrepreneurs.

Indian-owned businesses are distributed over all industries but are concentrated in different industries than the national average (see Table 3). Two of the most important

\footnotetext{
${ }^{10}$ Even if the list is expanded further to include very small groups, Indian entrepreneurs remain either the first or second highest income group.

${ }^{11}$ Only aggregate data are publicly available from these sources. Confidential and restricted-access microdata from these sources are available after going through an approval and disclosure process with the Center for Economic Studies at the U.S. Census and the IRS.

${ }^{12}$ See Georgarakos and Tatsiramos (2009) for evidence on survival rates among immigrant entrepreneurs for major racial groups.
} 
differences are that Indian entrepreneurs are less likely to be located in agriculture and construction. The construction industry comprises 17.4 percent of all businesses in the United States, however only 1.8 percent of Indian entrepreneurs are located in this industry. Indian firms are also less likely to concentrate in professional services and other services. Indian entrepreneurs are more likely than business owners as a whole to concentrate in retail trade, education, health and social services, and arts, entertainment and recreation. Overall, there are some differences between the industrial composition of Indian entrepreneurs and the national average, but there is a lot of overlap.

\section{INDIAN ENTREPRENEURS IN CANADA AND THE UNITED KINGDOM}

Are Indian entrepreneurs also more successful in Canada and the United Kingdom? Table 4 reports average business outcomes for Indian and Asian immigrants and all entrepreneurs in Canada and the United Kingdom. ${ }^{13}$ In Canada, Indian entrepreneurs earn slightly less than the average income among all entrepreneurs (\$28,580 versus \$30,296). ${ }^{14}$ In the Canadian Census, information on whether the business has employees (employer firms) is also available. Employment represents a rough proxy for business success. Employment rates are highly correlated with sales, profits and survival rates (U.S. Census Bureau 1997). Firms with more employees are less likely to fail, have higher sales, and have higher profits on average. Examining this information, we find that 48.4 percent of Indian entrepreneurs hire employees. This is higher than the national average of 42.4 percent. Unfortunately, earnings data is not available in the U.K. Census, and thus we focus on employment as an

\footnotetext{
${ }^{13}$ Business ownership rates for Indian immigrants are similar to the national average in Canada, but are somewhat higher in the U.K. (Fairlie, Zissimopoulos, and Krashinsky 2008).

${ }^{14}$ At the beginning of 2000, the exchange rate was 1.45 Canadian dollars per U.S. dollar (International Monetary Fund 2007).
} 
indicator of a business owner's achievement. Indian entrepreneurs are substantially more likely to hire employees than the national average (53.6 versus 37.1 percent). Overall, Indian entrepreneurs are more successful than the national average in Canada and the United Kingdom as measured by percent with employees, but slightly less so if income is used as a measure for Canada.

The industry distributions for Canada and the United Kingdom are reported in Tables 5 and 6, respectively. For Indian business owners in Canada, patterns in industrial concentration relative to the overall population of business owners are similar to those found in the United States: there is some variation in industrial composition for Indian entrepreneurs, but there is a great deal of overlap between Indians and the national average. Indians are less likely than the national average to own businesses in agricultural or construction industries, but are more likely to own businesses in the transportation industry.

Similarly, in the United Kingdom the major difference between the industry distribution for Indian entrepreneurs and all entrepreneurs are the lower concentrations of Indian business owners in agriculture and construction (Table 6). Indian entrepreneurs in the United Kingdom are highly concentrated in wholesale and retail trade with 41.9 percent in this industry compared to only 16.1 percent overall. Indian firms are also more concentrated in transport, storage and communication, and health and social work than the national average. Indian businesses in the United Kingdom are clearly more concentrated in specific industries than in the United States and Canada, which may contribute differently to their relative success. 


\section{Explanations for the Success of Indian Entrepreneurs}

Why are Indian entrepreneurs more successful than other entrepreneurs? One hypothesis is that Indian entrepreneurs are highly educated and this human capital contributes to their business success. We report group differences in education levels and other characteristics in Table 7. In all three countries, Indian entrepreneurs are more likely to be college graduates than native-born white entrepreneurs. We switch to comparing Indian entrepreneurs to native-born white entrepreneurs to create mutually exclusive categories for the following regression and decomposition analysis. Mean levels for the national average are very similar to those reported for native-born whites. ${ }^{15}$ More than two thirds of Indian entrepreneurs in the United States are college graduates, and half of all Indian entrepreneurs in Canada are college graduates, which is double the rate for native-born whites or the national average in both countries. ${ }^{16}$ In the United Kingdom just over one-third of Indian entrepreneurs are college educated, and while lower than in the United States and Canada, is still higher than the percent of college-educated native-born whites (21 percent). Indian entrepreneurs in all three countries are also much more likely to be married than native-born whites. The differences in other characteristics such as sex and age between Indian immigrant entrepreneurs and native-born white entrepreneurs are generally small.

Employing a multivariate regression model, we test the hypothesis that human capital contributes to the entrepreneurial success of Indian immigrants in each country, investigate other determinants of business performance, and use a decomposition technique to examine

\footnotetext{
${ }^{15}$ Decomposition estimates are also very similar whether native-born whites or the national average is used as the comparison group.

${ }^{16}$ Until the mid to late 1980s India spent more on higher education than primary and basic education. The large resulting stock of college graduates did not have complementary institutions and other capital to work with in India, and thus emigrated in large numbers to wealthy countries (Goldman, Kumar and Liu 2008).
} 
the relative importance of each of the determinants. ${ }^{17}$ We estimate separate regression models for log business income and/or employment by country. The models are the same for all countries and include an indicator variable for college degree or higher as a measure of education. We control for group differences with dummy variables for all major immigrant groups and native-born ethnic/racial groups with native-born whites, the single largest ethnic/racial group, as the excluded group. ${ }^{18}$ Other covariates include: female indicator; ages 25-29, 30-44 (excluded), 45-59, 60-64; indicator for married; and indicators for agriculture and construction industries (all other industries excluded). For the United States and Canada, we estimate specifications for log net business income, and for Canada and the United Kingdom, we estimate specifications for employment.

\section{U.S. RESULTS}

Table 8 reports results for the United States. Indian entrepreneurs are found to have roughly 50 percent higher earnings than native-born whites before controlling for other factors. These estimates indicate that the Indian entrepreneurial earnings advantage holds when the reference group is native-born whites and when taking logs (which lessens the influence of high-earnings outliers). In the second specification, we include controls for education, age, marital status, region, and broad industrial sector. ${ }^{19}$ The earnings differential for Indian entrepreneurs drops substantially after including these controls suggesting that

\footnotetext{
${ }^{17}$ Due to data limitations we cannot examine the importance of social capital which has been found to be important for Indian-owned businesses (see Kalnins and Cheung 2006 for example).

${ }^{18}$ We also include dummies for the largest Asian immigrant groups in each specification.

${ }^{19}$ We cannot control for year in the country in the U.K. data, and thus do not control for cohort effects (Borjas 1986; Schuetze and Antecol 2006), and do not examine assimilation patterns for Indian immigrants (Lofstrom 2002).
} 
differences in individual characteristics are largely responsible for why Indian entrepreneurs are so successful in the United States. We return to this finding below in the decompositions.

The returns to education on business performance are substantial. Having a college degree increases net business income by roughly 60 percent. Education is found to be a strong determinant of business earnings around the world consistent with this finding (see Parker 2004, van der Sluis, van Praag and Vijverberg 2004, and van Praag 2005). The coefficients on the other individual and job characteristics indicate that business income is higher among male owners, married owners, middle-aged owners, and non-agricultural businesses. Differences between Indian entrepreneurs and native-born white entrepreneurs in education and these other characteristics clearly contribute to the relative success of Indian entrepreneurs in the United States. In order to categorize the relative importance of education and the other characteristics we employ decomposition techniques.

\section{ADDITIONAL ESTIMATES}

Before turning to the decompositions, we estimate several additional specifications to check the sensitivity of the estimates. In the main results, we include all of the explanatory variables that are available and consistently defined across all three countries. One concern is that education might proxy for wealth instead of skill or aptitude. Limited access to financial resources may result in undercapitalized businesses and restrict the growth of businesses (Fairlie and Robb 2007, 2008). Measures of total wealth are unavailable in the U.S. Census, however, home ownership is available and the inclusion of this variable in the models does not alter either the estimated effect of Indian immigrants or education on business performance. 
We also estimate specifications that include more detailed education levels for the United States. We find that business ownership and income are increasing functions for each higher education level. The coefficient on the Indian immigrant dummy, however, is not sensitive to the switch from the inclusion of the college dummy variable to more detailed dummy variables. The U.S. Census also allows us to control for English language ability and number of children. The Indian dummy and college coefficients do not noticeably change with the inclusion of these variables.

Finally, we estimate a regression specification that includes dummy variables for more detailed industries similar to those reported in Table 3. The coefficient on the Indian dummy is now 0.176 which is not substantially different than Specification 2 where we include controls for agriculture and construction. Although there are differences in other industries, two of the largest differences in industry concentrations between Indian entrepreneurs and the national average are the under-representations in agriculture and construction, which are low-income industries. Controlling for more detailed industries does not alter the main results. Similar to most previous studies on self-employed business owners, we do not control for these more detailed industries because of concerns regarding whether they simply proxy for success. The human capital and other characteristics of the owner may determine whether the entrepreneur can start a business in certain high-income industries making the industry choice endogenous.

\section{DECOMPOSITIONS}

Estimates from the log business income regressions identify several determinants of business performance. If Indian entrepreneurs differ substantially from the national average 
in any of these characteristics then it could explain why Indian entrepreneurs are so successful. To explore these issues further, we employ the Blinder-Oaxaca technique of decomposing inter-group differences in a dependent variable into those due to different observable characteristics across groups (often referred to as the "endowment effect") and those due to different determinants of outcomes (often referred to as the "coefficient or unexplained effect") (see Blinder 1973 and Oaxaca 1973). The standard decomposition of the white/minority gap in the average value of the dependent variable, Y, can be expressed as:

(1) $\bar{Y}^{W}-\bar{Y}^{M}=\left\lfloor\left(\bar{X}^{W}-\bar{X}^{M}\right) \hat{\beta}^{W}\right\rfloor+\left\lfloor\bar{X}^{M}\left(\hat{\beta}^{W}-\hat{\beta}^{M}\right)\right\rfloor$.

We use log net business income as the dependent variable and define Indian entrepreneurs as the minority group.

Similar to most recent studies applying the decomposition technique, we focus on estimating the first component of the decomposition which captures contributions from differences in observable characteristics or "endowments." We do not report estimates for the second or "unexplained" component of the decomposition because it partly captures contributions from group differences in unmeasured characteristics and is sensitive to the choice of left-out categories making the results difficult to interpret. Another issue that arises in calculating the decomposition is the choice of coefficients or weights for the first component of the decomposition. The first component can be calculated using either the white or minority coefficients often providing different estimates, which is the familiar index problem with the Blinder-Oaxaca decomposition technique. An alternative method is to weight the first term of the decomposition expression using coefficient estimates from a pooled sample of the two groups (see Oaxaca and Ransom 1994 for example). We follow 
this approach to calculate the decompositions by using coefficient estimates from regressions that includes a sample of all racial groups. Finally, Equation (1) provides an estimate of the contribution of Indian/white differences in the entire set of independent variables to the income gap. We further decompose this component into the contributions from each set of independent variables included in the regression.

Table 9 reports estimates from this procedure for decomposing the Indian/white gaps in business outcomes. The most important factor explaining why Indian entrepreneurs perform better on average than white entrepreneurs in the United States is that they have higher levels of education. The education difference explains 43.9 percent of the gap in business income. The favorable sectoral distribution of Indian entrepreneurs explains 9.3 percent of the business income differential. ${ }^{20}$ In sum, all of the variables explain roughly three quarters of the gap in business income between Indians and the national average.

\section{CANADIAN RESULTS}

We now turn to the results for Canada. Estimates for log net business income regressions are reported in Table 10. Indian entrepreneurs do not have notably higher incomes than native-born white entrepreneurs in Canada. The point estimate in the log business income regression is positive, but small and insignificant. This is largely consistent with the estimates for average business income for Indian entrepreneurs and the national average reported in Table 4, but different than what was observed for relative earnings of Indian entrepreneurs in the United States. Another difference between the results for Canada and the United States is that the return to education is relatively lower in Canada. The

\footnotetext{
${ }^{20}$ Decomposition estimates from including more detailed industries provide a smaller contribution. Industry differences explain 5.8 percent of the gap in log business income.
} 
coefficients imply that business income for Canadians is roughly 50 percent higher among college educated owners, which is lower than the return of roughly 60 percent found in the United States. The other variables have similar estimated effects as for the United States -business income is higher for male, older and married entrepreneurs, and lower in agriculture. ${ }^{21}$

One similarity between the Canadian and American results, though, is that controlling for education and other individual characteristics reduces the Indian coefficient substantially. The coefficient is now negative and statistically significant. The point estimate implies that Indian entrepreneurs earn roughly 20 percent less than white entrepreneurs given their education levels and other characteristics. The decomposition estimates discussed below shed light on why this is the case. We also examine the determinants of hiring employees (also reported in Table 10). Having a college education is associated with business success measured by employment. Entrepreneurs with a college education are 7.2 percentage points more likely to hire employees than non-college educated entrepreneurs, which is a large effect relative to the mean employment rate of 45 percent. Married, male and middle-age entrepreneurs are also more likely to hire employees. ${ }^{22}$ Finally, agricultural firms are less likely to hire employees, and construction firms are slightly more likely to hire employees. These results are consistent with those for business income. One difference between the

\footnotetext{
${ }^{21}$ We estimate several additional specifications for Canada as robustness checks. First, we checked the sensitivity of the education and Asian immigrant dummies to the inclusion of home ownership. The coefficients are not sensitive to the inclusion of this asset measure. Second, we included more detailed education codes available in the Canadian Census. This also does not have a large effect on the Asian group coefficients. Finally, we included the number of children as an additional control and did not find changes in the group coefficients. Similar to the U.S. results, the Canadian results are robust to alternative specifications.

${ }^{22}$ The correlation between being married and having employees may be partly due to married entrepreneurs hiring their spouses, but there is a strong association between marriage and net business income.
} 
results, however, is that the coefficient on the Indian dummy variable drops from 5 percentage points to essentially zero. This implies that we can explain entirely why Indian entrepreneurs are more likely to hire employees than are white entrepreneurs in Canada.

To further investigate the importance of various characteristics on income and being an employer firm, decompositions for Canada are reported in Table 9. Focusing on the results for log business income first, we find that education contributes substantially to the difference in business income. We do not report percentage contributions because they can be misleading in decompositions when the gaps are relatively small. The focus instead is on the contribution estimates. Indian entrepreneurs are more educated than white entrepreneurs. Fifty percent have a college degree compared with 25.4 percent of white entrepreneurs. This educational advantage and the large positive returns to education for business income imply that Indian entrepreneurs should earn 12.5 log points more than white entrepreneurs in Canada, all else equal. Of course, not all else is equal and other factors, which are largely unobservable, work to suppress the incomes of Indian entrepreneurs.

Higher marriage rates, lower female shares, and overrepresentation in British Columbia and Ontario among Indian entrepreneurs contribute slightly to higher business incomes. Differences in industry structure are advantageous for Indian entrepreneurs. Indian entrepreneurs are less likely to locate in agriculture explaining 4.4 log points of the gap in business income. The decomposition estimates indicate that differences in education and other observable characteristics should result in Indian entrepreneurs earning roughly 25 percent more than white entrepreneurs. Unobservable factors, which may include discrimination, non-transferable credentials and differences in preferences, reduce this advantage to 6 percent. 
The employer decompositions indicate that higher rates of employment among Indian entrepreneurs are partly due to higher education levels. Higher education levels among Indian entrepreneurs contribute 1.8 percentage points to the difference in employment rates. Higher marriage rates, male shares and advantaged regional distributions also contribute slightly to why Indian entrepreneurs are more likely to hire employees. Taken together, these factors explain more than the entire gap in employment rates between Indian and white businesses. $^{23}$

\section{U.K. RESULTS}

Estimates for employer regressions for the United Kingdom are reported in Table 11. Unfortunately, we do not have a measure of business income in the United Kingdom, and thus only report results for employment. Employer firms are more likely among male, married and middle-aged owners, and non-agricultural, non-construction businesses, which is generally consistent with the results for log business income for the United States and Canada. Most importantly, we find a positive and statistically significant effect of education on employment. ${ }^{24}$ The coefficient estimate indicates that college-graduate owners have a 1.8

\footnotetext{
${ }^{23}$ The total contribution from all variables can exceed $100 \%$ if there are unobservable factors providing a negative and offsetting contribution to the gap (Blinder 1973 and Oaxaca 1973).

${ }^{24}$ For the United Kingdom, we assessed the sensitivity of the Indian and education dummies to the inclusion of a home ownership indicator in the employer firm regressions and found the estimates were insensitive to this inclusion. Second, we included an indicator for each level of qualifications including no qualifications (with levels 4 and 5 as the excluded group). We find that there is no difference in the effect of level 2 qualifications or level 3 qualifications, relative to level 4 or 5, on business ownership and employer firm. Having no qualifications reduces business ownership and being an employer firm by 1.3 percentage points and 2.6 percentage points respectively and having level one qualifications reduces business ownership and being an employer firm by 2.6 percentage points and 2.7 percentage points respectively. These estimates are statistically different from zero, but small. The inclusion of more detailed education indicators has no effect on the Indian dummy. Finally, we included the number of usual household residents in the regressions and found that it had no effect on the estimated Indian immigrant indicators. The U.K. results are thus not overly sensitive to alternative specifications.
} 
percentage point higher likelihood of hiring employees than do owners with lower levels of education. The positive effect of education on employment is consistent with the estimated effects of education on log business income in the United States and Canada, but the relative magnitude of the effect is much smaller. The estimated effect on British employment represents roughly 5 percent of the mean employment rate compared to roughly 15 percent on Canadian employment. Additionally, the returns to a college education are 60 percent of business income in the United States and 50 percent of business income in Canada.

The inclusion of education and other covariates decreases the coefficient estimates on the Indian dummy variable. Indian entrepreneurs are 17 percentage points more likely to hire employees than white entrepreneurs, which drops to 12.5 percentage points after controlling for the independent variables. The decomposition estimates reported in Table 9 indicate that high levels of education among Indian entrepreneurs contribute very little to why they are more likely to hire employees. The estimated effect of education on employment is too weak even though the educational difference is large (although much smaller than in the United States). Thirty-six percent of Indian entrepreneurs have the equivalent of a college education compared with 21.4 percent of white entrepreneurs. Higher marriage rates and lower concentrations in agriculture and construction contribute to why Indian entrepreneurs are more successful in hiring employees than native British entrepreneurs.

\section{EDUCATION DIFFERENCES AND IMMIGRATION POLICIES}

The finding that Indian entrepreneurs in the United States are more likely to be college educated than Indian entrepreneurs in Canada and the United Kingdom compared to the national average may be due to differences in immigration policies and who selects to 
come to each country. Although differences in labor markets, credit markets, tax systems, historical ties, geographical proximity, and other institutional and structural differences are also important, immigration policy is clearly one of the most important factors affecting who emigrates. Although a detailed discussion of differences in immigration policies in the United States, Canada and the United Kingdom is beyond the scope of this paper, a brief discussion of types of immigrant admissions highlights key differences across countries. ${ }^{25}$

Figure 1 reports immigration admissions by type for the United States, Canada, and the United Kingdom. In both the United States and United Kingdom immigrants are most likely to enter the country as 'family sponsored.' Since the 1960s U.S. immigration policy has strongly favored family reunification (Woroby 2005) and has been criticized for lowering the skills and education levels of successive waves of immigrants (Borjas 1995, 1999). The United Kingdom's immigration policies were at one time restricted to citizens of the states in the Commonwealth. However, over the past four decades the policies in the United Kingdom have shifted towards emphasizing family reunification and employment (Bauer, Lofstrom \& Zimmermann 2001). On the other hand, Canada's point-based system which awards immigration admission points based on education, language ability (English or French), years of experience in a managerial, professional or technical occupation, age, arranged employment in Canada, and other factors leads to more skilled immigrants compared to the United States (Borjas 1993, Woroby 2005). ${ }^{26}$ Because of the point-based system, roughly half of all immigrants are admitted through employment-based preferences (Figure 1). In

\footnotetext{
${ }^{25}$ See Bauer, Lofstrom and Zimmermann (2000), Antecol, Cobb-Clark and Trejo (2003), Woroby (2005), and Schuetze and Antecol (2006) for more information on immigration policies. ${ }^{26}$ Antecol, Cobb-Clark and Trejo (2003) find that Canadian immigrants have higher skills than U.S. immigrants, but the disparity disappears after removing Latin American immigrants, which is roughly similar to the finding in Borjas (1993). They argue, however, that policy differences are less important than geographical and historical differences.
} 
contrast, slightly more than 10 percent of immigrants in the United States are admitted under this broad classification.

The related category of employment creation or investors differs across countries. ${ }^{27}$ In Canada these immigrants are categorized as ‘investors', ‘entrepreneurs’, or ‘selfemployed'. There are minimum net worth and business experience requirements for investors and entrepreneurs, and self-employed immigrants must have relevant experience in cultural, athletic or farm management occupations. ${ }^{28}$ In the United States, immigrants admitted in the ‘employment creation’ must be actively investing at least \$1 million U.S. dollars in a commercial enterprise with at least 10 employees. 'Business' immigrants to the United Kingdom must invest a minimum of $£ \$ 200,000$, and 'innovator' immigrants must employ at least two U.K. residents. The estimates reported in Figure 1 indicate that a larger, but still relatively small, share of immigrants in Canada are admitted under these policies than in the United States and United Kingdom. In Canada, they represent 7 percent of all admitted immigrants compared to 0.1 and 2.4 percent in the United States and United Kingdom, respectively. Differences in these policies may alter the percent of successful immigrant business owners across countries, but overall only a small share of immigrants enter all three countries through this path.

Canada's point based immigration system results in a higher share of employmentbased immigrants compared to the United States and United Kingdom. On the other hand, the United Kingdom admits a much higher share of immigrants under its refugee and asylee

\footnotetext{
${ }^{27}$ See Citizenship and Immigration Canada (2007) for more information on the Canadian selection criteria, U.S. Citizenship and Immigration Services (2007) for requirements for employment creation immigrants, and U.K. Border and Immigration Agency (2007) for U.K. investment immigration information.

${ }^{28}$ For investors and entrepreneurs the minimum net worth requirements are $\$ 800,000$ and $\$ 300,000$, respectively, and at least 2 years worth of business experience.
} 
programs than the United States or Canada. All else equal, we would expect skill levels of immigrants to be the highest in Canada and the lowest in the United Kingdom. As indicated above we find some evidence that the educational advantage of Asian immigrants compared to the national average is lower in the United Kingdom than in the United States, which is consistent with these differences in immigration policies. But, we also find that the educational advantage in the United States is higher than it is in Canada, which runs counter to the greater emphasis of Canada's immigration policy on rewarding points for the general skill level of immigrants. A more generous redistribution system, more egalitarian earnings, and other institutional and structural factors, however, may make Canada less attractive to higher skilled immigrants such as Indian immigrants (Antecol, Cobb-Clark and Trejo 2003).

\section{Conclusions}

Over 1 million Indians have migrated to the United States making it the largest receiving country in the world. Nearly another million Indians have migrated to Canada and the United Kingdom, which have received the next largest waves of Indian immigrants besides Bangladesh (World Bank 2007). Indians also represent either the largest or one of the largest single immigrant groups in each of these countries. In the United States, for example, only immigrants from Mexico, the Phillippines and Germany represent larger shares of the total population. Given the importance of this migration, we use Census microdata from the United States, Canada and United Kingdom, to provide the first comparative examination of the performance of Indian entrepreneurs.

We find that Indian entrepreneurs are much more successful than the national average in the United States. Indian businesses also perform well in Canada and the United 
Kingdom, but the evidence is not as strong. In the United States, Indian entrepreneurs earn 60 percent more than white entrepreneurs and have the highest average business income of any immigrant group. Estimates from business-level data sources also indicate that Indian firms have higher profits, hire more employees, and have lower failure rates than the average for all U.S. firms (Fairlie and Robb 2008, U.S. Census Bureau 2007).

To explain the relative success of Indian entrepreneurs we focus on the role of human capital. In particular, we test the hypothesis that a highly-educated Indian entrepreneurialforce is responsible for their superior performance in business. Indian immigrants in all three countries have education levels that are higher than the national average, and in the United States the education levels of Indian immigrants are particularly high relative to the entire population. In the United States, 68 percent of Indian entrepreneurs have a college education which is twice the rate for whites or the national average. Some of the variation in the education of Indian immigrants across the United States, Canada and United Kingdom is likely due to immigration policy. Another possibility is that the higher returns to education in the United States result in a more selective immigrant pool in the United States compared to Canada and the United Kingdom.

Estimates from regression models for log business income and employment reveal interesting differences across the three countries. When we examine business income, we find large, positive effects of education in the United States and Canada. We also find large positive effects of education on employment in Canada, but smaller positive effects in the United Kingdom. The findings for education imply that the relatively high levels of education among Indian entrepreneurs have a large effect on business performance at least in the United States and Canada. Decomposition estimates provide exact estimates of the 
contribution of higher levels of education among Indian entrepreneurs to their higher business incomes and employment levels. In the United States, higher levels of education among Indian entrepreneurs result in a business income advantage of 21 log points, which represents 43.9 percent of the gap. High levels of education also contribute substantially to why Indian entrepreneurs earn more in Canada (12.5 log points), but the difference is not as large. The combination of the larger education advantage held by Indian entrepreneurs and the larger return to education is responsible for the increased importance of education as an explanatory factor in the United States compared to Canada. In contrast to these results, the smaller educational advantage and lower returns to education in the United Kingdom result in less explanatory power in the United Kingdom. Lower concentrations of Indian entrepreneurs in agriculture and construction, lower female share, higher marriage rates, and favorable regional distributions also generally contribute to why Indian businesses perform better than white businesses or the national average.

Indian entrepreneurs contribute substantially to their host economies. Indian firms hire 610 thousand employees and have total sales of $\$ 88$ billion in the United States alone (U.S. Census Bureau 2007). In Canada, and especially in the United Kingdom, Indian entrepreneurs are more likely to hire employees. From India's perspective, these findings have implications for "brain drain." Although concerns over "brain drain" usual focus on the loss of highly educated workers in professional occupations, the loss of entrepreneurial talent is also important. The loss of Indian entrepreneurial talent to developed countries such as the United States, Canada and United Kingdom may have severe consequences for aggregate income, the creation of wealth, and employment. In addition to examining the potential 
benefits of Indian entrepreneurs in the host country, as is done here, more research is needed to explore the potential costs to India.

Census data, while rich along many dimensions, limit our efforts to pursue additional avenues of research including the selection of Indian immigrants to host countries and the selection into entrepreneurship. It is likely that the returns to education are much larger for entrepreneurs in the countries we study than in India, which causes them to emigrate. Van der Sluis, van Praag, and Vijverberg (2005) conduct a meta-analytical empirical review and note that the return to schooling in terms of enterprise income in developing economies is actually comparable to that of industrial countries. But they also note that educated people prefer wage employment to nonfarm entrepreneurship, an effect that is stronger in economies where agriculture is dominant and literacy rates are lower. Nearly two-thirds of the Indian labor force is in agriculture and only around $60 \%$ of its population is literate. ${ }^{29}$ Therefore, it is likely that educated Indians who want to become entrepreneurs are more likely to start their enterprises in the wealthy countries rather than at home.

The challenge in identifying who chooses to become an entrepreneur is finding an identifying restriction - a variable that affects the entrepreneurship choice, but not earnings and such an instrument has yet to be identified and employed in empirical work. Finally, immigration differences appear unable to explain all the differences in the strong performance of Indian entrepreneurs in the U.S. relative to Canada and the U.K. In addition to immigration policies, credit and labor markets, among other institutional features are likely to matter. To incorporate these considerations we would need a structured framework that simultaneously examines the decision to become an entrepreneur as opposed to a worker and

\footnotetext{
${ }^{29}$ See, for instance, World Bank’s India at a Glance, devdata.worldbank.org/AAG/ind aag.pdf.
} 
the choice of a national location. ${ }^{30}$ Our systematic exploration of Indian entrepreneurs in varied developed countries places us in a good position to pursue these issues in future work.

${ }^{30}$ Princeton's New Immigrant Survey (http://nis.princeton.edu/) might be useful in this regard. This survey gathers more details than the censuses do on the last job held by new immigrants, including details on selfemployment. 


\section{References}

Agrawal, Ajay, Devesh Kapur, and John McHale. 2008. "Brain Drain or Brain Bank? The Impact of Skilled Emigration on Poor-country Innovation.” NBER Working Paper 14592.

Antecol, Heather, Deborah A. Cobb-Clark, and Stephen J. Trejo. 2003. "Immigration Policy and the Skills of Immigrants, Journal of Human Resources, 38(1): 192-218.

Bauer, Thomas K., Magnus Lofstrom, and Klaus F. Zimmermann. 2000. Immigration Policy, Assimilation of Immigrants and Natives' Sentiments towards Immigrants: Evidence from 12 OECD-Countries. Discussion Paper. Bonn, Germany: Institute for the Study of Labor.

Blinder, Alan S. 1973. "Wage Discrimination: Reduced Form and Structural Variables." Journal of Human Resources 8: 436-455.

Borjas, George. 1986. "The Self-Employment Experience of Immigrants." Journal of Human Resources, 21, Fall: 487-506.

Borjas, George. 1987. "Self-Selection and the Earnings of Immigrants." American Economic Review, 77, pp. 531-553.

Borjas, George. 1993. "Immigration Policy, National Origin, and Immigrant Skills: A Comparison of Canada and the United States." in Small Differences that Matter: Labor Markets and Income Maintenance in Canada and the United States, eds. David Card and Richard B. Freeman, 21-43. Chicago: University of Chicago Press.

Borjas, George. 1995. "Assimilation and Changes in Cohort Quality Revisited: What Happened to Immigrant Earnings in the 1980s?" Journal of Labor Economics, 13(2): 201-45.

Borjas, George. 1999. Heaven's Door: Immigration Policy and the American Economy. Princeton, NJ: Princeton University Press.

Cervantes, Mario and Dominique Guellec. 2002. OECD Observer, 230.

Citizenship and Immigration Canada. 2007. "Investors, entrepreneurs and self-employed persons," http://www.cic.gc.ca/english/immigrate/business/index.asp and http://www.cic.gc.ca/english/immigrate/business/self-employed/index.asp

Clark, Kenneth and Stephen Drinkwater. 1998. "Ethnicity and Self-Employment in Britain." Oxford Bulletin of Economics and Statistics. 60, pp.383-407. 
Clark, Kenneth and Stephen Drinkwater. 2000. "Pushed out or pulled in? Self-employment among ethnic minorities in England and Wales." Labour Economics. 7, pp.603-628.

Clark, Kenneth and Stephen Drinkwater. 2006. "Changing Patterns of Ethnic Minority SelfEmployment in Britain: Evidence from Census Microdata," IZA Discussion Papers 2495, Bonn, Germany: Institute for the Study of Labor (IZA)

Clark, Ken, S. Drinkwater and D. Leslie. 1998. Ethnicity and Self-Employment Earnings in Britain 1973-1995, Applied Economic Letters, 5: 631-634.

Docquier, Frederic and Abdeslam Marfouk. 2005. "International Migration by Educational Attainment," in International Migration, Remittances, and the Brain Drain, Caglar Ozden and Maurice Schiff, eds., Washington D.C. and New York: The World Bank and Palgrave Macmillan.

Dudley, Jill and Paul Harvey, "Control of Immigration statistics: United Kingdom, 2000", Immigration Research and Statistics Service, United Kingdom 2001.

Fairlie Robert W., Julie Zissimopoulos, and Harry A. Krashinsky. 2008. "The International Asian Business Success Story: A Comparison of Chinese, Indian and Other Asian Businesses in the United States, Canada and United Kingdom," in International Differences in Entrepreneurship, eds. Josh Lerner and Antoinette Shoar, National Bureau of Economic Research Press (forthcoming).

Fairlie, Robert W., and Alicia M. Robb. 2007. "Why are Black-Owned Businesses Less Successful than White-Owned Businesses: The Role of Families, Inheritances, and Business Human Capital," Journal of Labor Economics, 25(2): 289-323.

Fairlie, Robert W., and Alicia Robb. 2008. Race and Entrepreneurial Success: Black-, Asian, and White-owned Businesses in the United States. Cambridge: MIT Press.

Georgarakos, Dimitris, and Konstantinos Tatsiramos. 2009. "Entrepreneurship and Survival Dynamics of Immigrants to the U.S. and their Descendants," Labour Economics, 16(2), May: 161-170.

Goldman, Charles A., Krishna B. Kumar and Ying Liu. 2008. "Education and the Asian Surge: A Comparison of the Education Systems in India and China." RAND Occasional Paper 218.

Hout, Michael and Harvey S. Rosen. 2000. "Self-Employment, Family Background, and Race," Journal of Human Resources., 35 (4): 670-692.

International Monetary Fund. 2007. "Representative Exchange Rates for Selected Currencies for January 2000," www.imf.org/external/np/fin/data/rms_mth.aspx?SelectDate=2000-0131\&reportType $=$ REP 
Johnson, P.J. (2000) Ethnic differences in self-employment among Southeast Asian refugees in Canada. Journal of Small Business Management 38:4, 78.

Kalnins, Arturs, and Wilbur Chung. 2006. Social Capital, Geography, and Survival: Gujarati Immigrant Entrepreneurs in the U.S. Lodging Industry," Management Science, 2006, 52(2): 233-247.

Khadria, Binod. 1999. The migration of knowledge workers: second-generation effects of India's brain drain. New Delhi: Sage Publications.

Kim, Kwang, Won Hurh, and Maryilyn Fernandez. 1989. “Intragroup Differences in Business Participation: Three Asian Immigrant Groups,” International Migration Review 23(1).

Ley, D. (2006) Explaining variations in business performance among immigrant entrepreneurs in Canada. Journal of Ethnic and Migration Studies 32:5, 743-764.

Li, P. (2001) Immigrants' propensity to self-employment: Evidence from Canada. International Migration Review 35:4, 1106-1128.

Lofstrom, Magnus. 2002. "Labor market assimilation and the self-employment decision of immigrant entrepreneurs", Journal of Population Economics, 15(1), January, 83-114.

Mar, Don. 2005. "Individual Characteristics vs. City Structural Characteristics: Explaining Self-Employment Differences among Chinese, Japanese, and Filipinos in the United States,” Journal of Socio-Economics, 34.

Metcalf, Hilary, Tariq Modood and Satnam Virdee. 1996. "Asian Self-Employment: The Interaction of Culture and Economics in England," London: Policy Studies Institute.

Oaxaca, Ronald. 1973. "Male-Female Wage Differentials in Urban Labor Markets," International Economic Review, 14 (October), 693-709.

Oaxaca, Ronald, and Michael Ransom. 1994. "On Discrimination and the Decomposition of Wage Differentials," Journal of Econometrics, 61, 5-21.

Parker, Simon C. 2004. The Economics of Self-Employment and Entrepreneurship. Cambridge: Cambridge University Press.

Parsons, Christopher R, Ronald Skeldon, Terrie L. Walmsley and L. Alan Winters (2005) Quantifying the International Bilateral Movements of Migrants, Mimeo. The World Bank and the Development Research Centre on Migration, Globalisation and Poverty at Sussex University. 
Saxenian, Annalee. 1999. Silicon Valley's New Immigrant Entrepreneurs, San Francisco: Public Policy Institute of California.

Saxenian, Annalee. 2000. "Networks of Immigrant Entrepreneurs," in The Silicon Valley Edge: A Habitat for Innovation and Entrepreneurship, eds. Chong-Moon Lee, William F. Miller, and Henry S. Rowen, Stanford: Stanford University Press.

Saxenian, Annalee. 2006. The New Argonauts: Regional Advantage in a Global Economy, Cambridge, MA: Harvard University Press.

Schuetze, Herbert J., and Heather Antecol. 2006. "Immigration, Entrepreneurship and the Venture Start-up Process," The Life Cycle of Entrepreneurial Ventures, International Handbook Series on Entrepreneurship, Vol. 3, ed. Simon Parker. Springer: New York.

Singh, Surjit. 2004. "Immigration into Canada: Some Issues" Indian Journal of Labour Economics, 47(2), April-June, pp. 349-67.

U.K. Border and Immigration Agency. 2007. "Law and Policy: Part 6 Persons Seeking to Remain in the United Kingdom," http://www.ind.homeoffice.gov.uk/lawandpolicy/immigrationrules/part6

U.S. Census Bureau. 1997. 1992 Economic Census: Characteristics of Business Owners. Washington, D.C.: U.S. Government Printing Office.

U.S. Census Bureau. 2006. 2002 Economic Census, Survey of Business Owners Asian-Owned Firms, Washington, D.C.: USGPO.

U.S. Citizenship and Immigration Services. 2007. "Employment Creation Entrepreneur Cases," http://www.uscis.gov/propub/ProPubVAP.jsp?dockey=987fe2c6b1c3f9e6725655e39 $\underline{\mathrm{a} 26 \mathrm{a} 247}$

van der Sluis, Justin, van Praag, Mirjam, and Vijverberg, Wim. 2004. Education and Entrepreneurship in Industrialized Countries: A Meta-Analysis. Tinbergen InstituteWorking Paper no. TI 03-046/3, Amsterdam: Tinbergen Institute.

van der Sluis, Justin, van Praag, Mirjam, and Vijverberg, Wim. 2005. “Entrepreneurship Selection and Performance: A Meta-Analysis of the Impact of Education in Developing Economies,” The World Bank Economic Review, 19(2), pp. 225-261.

van Praag, Mirjam. 2005. "Successful Entrepreneurship: Confronting Economic Theory with Empirical Practice," Cheltenham, UK ; Northampton, MA : E. Elgar.

van Stel, André, Martin Carree, and Roy Thurik. 2005. The Effect of Entrepreneurial Activity on National Economic Growth. Small Business Economics, 24: 311-321. 
Wadhwa, Vivek, AnnaLee Saxenian, Ben Rissing, and Gary Gereffi. 2007. "America’s New Immigrant Entrepreneurs," Duke University Report.

Woroby, Tamara. 2005. Should Canadian immigration policy be synchronized with U.S. immigration policy? Lessons learned at the start of two centuries. American Review of Canadian Studies, 35(2): 247-65.

Xu, Lei; Liaw, Kao-Lee. 2006. "Initial Destination Choices of Skilled-Worker Immigrants from South Asia to Canada: Assessment of the Relative Importance of Explanatory Factors" Canadian Journal of Regional Science, 29(2), Summer, pp. 299-320.

Zissimopoulos, Julie, Nicole Maestas and Lynn Karoly. 2007. "Retirement Transitions of the Self-employed in the United States and England” MRRC WP2007-155. 
Figure 1

Immigration by Type of Admission for 1998-2000

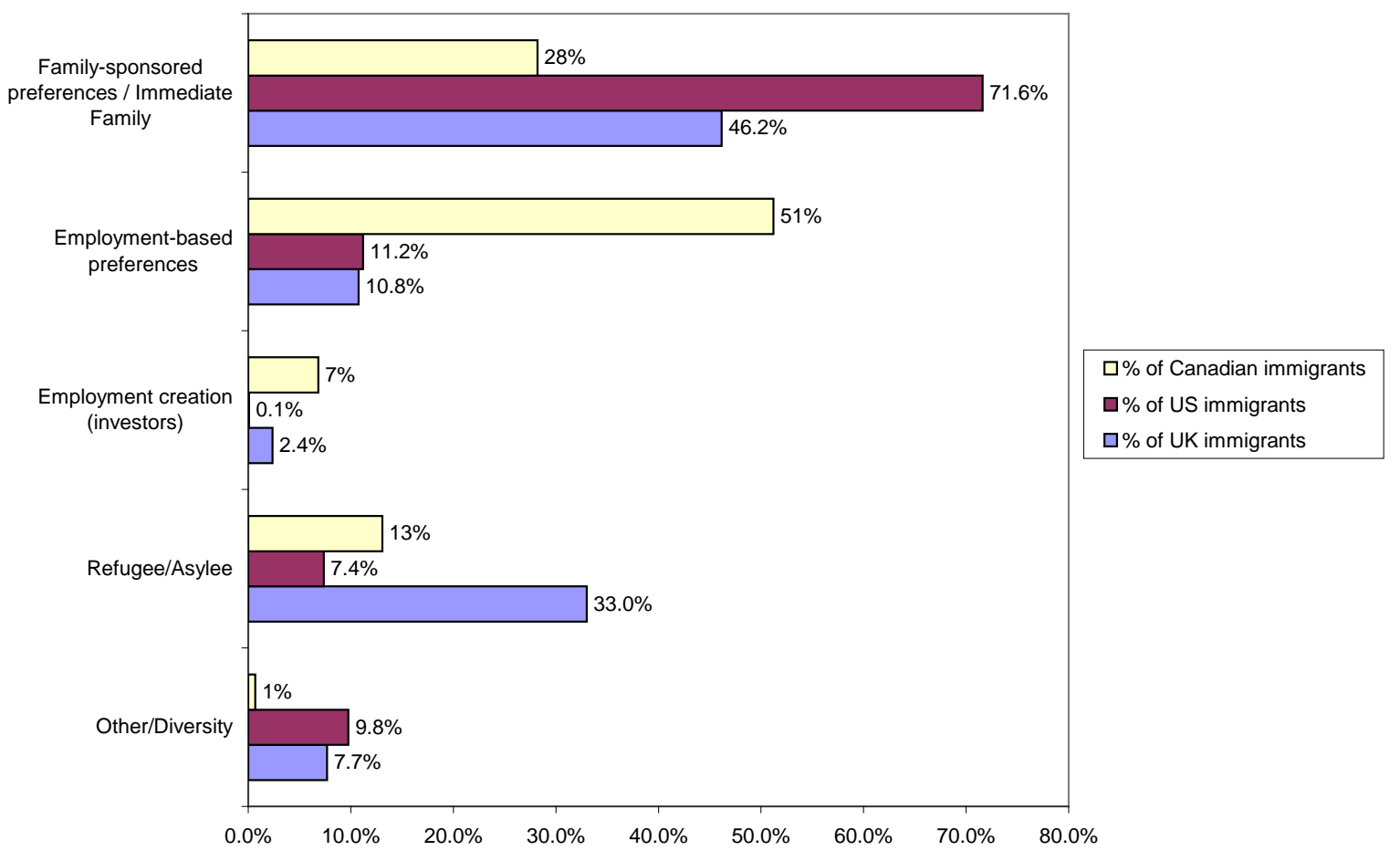


Table 1

Business Outcomes by Country of Origin

U.S. Census 2000

\begin{tabular}{lcc} 
Immigrant Group & $\begin{array}{c}\text { Net Business } \\
\text { Income }\end{array}$ & $\mathrm{N}$ \\
\hline U.S. Total & $\$ 52,086$ & 534,194 \\
All Asian Immigrants & $\$ 54,208$ & 17,093 \\
Indian Immigrants & $\$ 84,080$ & 2,684 \\
\hline Note: The sample consists of all business owners ages 25-64.
\end{tabular}


Table 2

Net Business Income for Detailed Immigrant Groups

U.S. Census 2000

\begin{tabular}{|c|c|c|}
\hline Source Country & $\begin{array}{l}\text { Net Business } \\
\text { Income }\end{array}$ & Sample Size \\
\hline India & 84,080 & 2,684 \\
\hline Iran & 77,452 & 1,473 \\
\hline Egypt & 69,707 & 352 \\
\hline Canada & 68,795 & 2,208 \\
\hline Lebanon & 66,500 & 512 \\
\hline Israel & 65,499 & 632 \\
\hline Iraq & 64,201 & 311 \\
\hline Hungary & 63,283 & 311 \\
\hline United Kingdom & 63,278 & 414 \\
\hline Pakistan & 61,701 & 621 \\
\hline Greece & 61,021 & 881 \\
\hline Other Asian & 60,981 & 665 \\
\hline Philippines & 59,990 & 1,634 \\
\hline Taiwan & 59,192 & 1,085 \\
\hline England & 58,672 & 1,238 \\
\hline Germany & 57,877 & 1,750 \\
\hline Netherlands & 57,706 & 353 \\
\hline Argentina & 56,523 & 469 \\
\hline Russia & 55,749 & 617 \\
\hline Japan & 55,192 & 775 \\
\hline Romania & 54,496 & 368 \\
\hline France & 52,184 & 419 \\
\hline Italy & 51,809 & 1,457 \\
\hline Ireland & 51,512 & 510 \\
\hline Cuba & 50,868 & 2,070 \\
\hline Nigeria & 48,811 & 319 \\
\hline Portugal & 48,561 & 480 \\
\hline Korea & 48,074 & 4,015 \\
\hline Ukraine & 46,177 & 454 \\
\hline China & 45,815 & 2,481 \\
\hline Poland & 43,801 & 1,228 \\
\hline Haiti & 41,156 & 378 \\
\hline Peru & 36,887 & 604 \\
\hline Jamaica & 36,714 & 780 \\
\hline Vietnam & 34,862 & 2,253 \\
\hline Colombia & 34,375 & 1,116 \\
\hline Nicaragua & 32,624 & 349 \\
\hline Brazil & 31,237 & 675 \\
\hline Ecuador & 29,906 & 491 \\
\hline Mexico & 28,153 & 11,008 \\
\hline Dominican Republic & 27,716 & 828 \\
\hline El Salvador & 27,481 & 1,383 \\
\hline Honduras & 24,545 & 367 \\
\hline Guatemala & 23,419 & 774 \\
\hline
\end{tabular}

Notes: (1) The sample consists of all business owners ages 2564. (2) All immigrant groups with a sample size of 300 or more are reported. 
Table 3

Industry Distribution of Indian Immigrant Businesses

U.S. Census (2000)

Indian

U.S. Total Immigrants

\begin{tabular}{lcc}
\hline Agriculture and mining & $5.8 \%$ & $1.0 \%$ \\
Construction & $17.4 \%$ & $1.8 \%$ \\
Manufacturing & $4.6 \%$ & $3.3 \%$ \\
Wholesale trade & $3.3 \%$ & $5.6 \%$ \\
Retail trade & $10.1 \%$ & $21.1 \%$ \\
Transportation & $3.8 \%$ & $5.5 \%$ \\
Information & $1.6 \%$ & $0.7 \%$ \\
FIRE & $7.6 \%$ & $5.7 \%$ \\
Professional services & $18.5 \%$ & $13.8 \%$ \\
Education, health and social services & $10.5 \%$ & $22.9 \%$ \\
Arts, entertainment and recreation & $5.9 \%$ & $14.5 \%$ \\
Other services & $10.8 \%$ & $4.0 \%$ \\
Sample size & 534,194 & 2,684 \\
\hline
\end{tabular}

Notes: (1) The sample consists of individuals ages 25-64 who own a business with 15 or more hours worked per week. (2) All estimates are calculated using sample weights provided by the Census. 
Table 4

Business Outcomes by Country of Origin

Canada Census 2001 and U.K. Census 2001

\begin{tabular}{|c|c|c|c|c|c|}
\hline \multirow[b]{2}{*}{ Immigrant Group } & \multirow{2}{*}{$\begin{array}{l}\text { Net Business } \\
\text { Income }\end{array}$} & \multirow{2}{*}{$\begin{array}{c}\text { Canada } \\
\text { Percent } \\
\text { Employer } \\
\text { Firms }\end{array}$} & \multicolumn{3}{|c|}{$\begin{array}{l}\text { United Kingdom } \\
\text { Percent } \\
\text { Employer }\end{array}$} \\
\hline & & & $\mathrm{N}$ & Firms & $\mathrm{N}$ \\
\hline Total & $\$ 30,296$ & $42.4 \%$ & 39,933 & $37.1 \%$ & 84,439 \\
\hline All Asian Immigrants & $\$ 24,301$ & $51.4 \%$ & 2,652 & $54.5 \%$ & 3,002 \\
\hline Indian Immigrants & $\$ 28,580$ & $48.4 \%$ & 539 & $53.6 \%$ & 1,111 \\
\hline
\end{tabular}


Table 5

Industry Distribution of Indian Immigrant Businesses

Canada Census (2000)

\begin{tabular}{lcc} 
& $\begin{array}{c}\text { Canada } \\
\text { Total }\end{array}$ & $\begin{array}{c}\text { Indian } \\
\text { Immigrants }\end{array}$ \\
\hline Agriculture and mining & $12.7 \%$ & $3.0 \%$ \\
Construction & $13.1 \%$ & $4.5 \%$ \\
Manufacturing & $5.0 \%$ & $5.0 \%$ \\
Wholesale trade & $3.9 \%$ & $5.4 \%$ \\
Retail trade & $12.0 \%$ & $14.8 \%$ \\
Transportation & $4.8 \%$ & $20.4 \%$ \\
Communication & $1.0 \%$ & $0.6 \%$ \\
FIRE & $3.9 \%$ & $5.0 \%$ \\
Business services & $15.8 \%$ & $14.1 \%$ \\
Government services & $0.1 \%$ & $0.0 \%$ \\
Education, health and social services & $10.6 \%$ & $12.2 \%$ \\
Accomodation, bood and beverage serv. & $4.4 \%$ & $6.3 \%$ \\
Other services & $12.8 \%$ & $8.7 \%$ \\
Sample size & 39,933 & 539 \\
\hline
\end{tabular}

Notes: (1) The sample consists of individuals ages 25-64 who own a business with 15 or more hours worked per week. (2) All estimates are calculated using sample weights provided by the Census. 
Table 6

Industry Distribution of Indian Immigrant Businesses

U.K. Census (2001)

Indian

U.K. Total Immigrants

\begin{tabular}{lcc}
\hline Agriculture, Hunting and Forestry & $5.7 \%$ & $0.0 \%$ \\
Fishing & $0.1 \%$ & $0.0 \%$ \\
Mining and Quarrying & $0.1 \%$ & $0.1 \%$ \\
Manufacturing & $8.9 \%$ & $7.5 \%$ \\
Electricity, Gas and Water Supply & $0.3 \%$ & $0.2 \%$ \\
Construction & $20.1 \%$ & $7.8 \%$ \\
Wholesale and Retail Trade; Repair of Mo & $16.1 \%$ & $41.9 \%$ \\
Hotels and Restaurants & $5.3 \%$ & $5.2 \%$ \\
Transport, Storage and Communication & $6.7 \%$ & $10.8 \%$ \\
Financial Intermediation & $2.2 \%$ & $2.3 \%$ \\
Real Estate, Renting and Business Activi & $17.2 \%$ & $9.0 \%$ \\
Public Administration and Defence; Compu & $0.8 \%$ & $0.5 \%$ \\
Education & $2.3 \%$ & $1.4 \%$ \\
Health and Social Work & $6.3 \%$ & $10.1 \%$ \\
Other Community, Social and Personal Ser & $7.8 \%$ & $3.1 \%$ \\
Private Households Employing Domestic St & $0.1 \%$ & $0.1 \%$ \\
Extra - Territorial Organisations and Bo & $0.0 \%$ & $0.0 \%$ \\
Sample size & 84,439 & 1,111 \\
\hline Notes: (1) The sample consists of individuals ages 25-64 who own a business with \\
15 or more hours worked per week. (2) UK includes England and Wales only. For \\
UK 'Asian immigrants' group is defined by country of birth and self-reported ethnicity \\
and does not include all persons born in Asia and residing in the UK. For example, \\
does not include ethnic British born in India.
\end{tabular}


Table 7

Mean Education and Characteristics among Indian and White Entrepreneurs

U.S. Census 2000, Canada Census 2001, and U.K. Census 2001

\begin{tabular}{lcccccc} 
& \multicolumn{2}{c}{ United States } & \multicolumn{2}{c}{ Canada } & \multicolumn{2}{c}{ United Kingdom } \\
& Indians & Whites & Indians & Whites & Indians & Whites \\
\hline College graduate & $68.3 \%$ & $34.6 \%$ & $50.0 \%$ & $25.4 \%$ & $35.8 \%$ & $21.4 \%$ \\
Female & $25.7 \%$ & $31.1 \%$ & $26.6 \%$ & $31.8 \%$ & $27.7 \%$ & $24.8 \%$ \\
Ages 25-29 & $4.3 \%$ & $5.8 \%$ & $5.0 \%$ & $5.1 \%$ & $2.6 \%$ & $6.4 \%$ \\
Ages 45-59 & $47.1 \%$ & $44.6 \%$ & $43.3 \%$ & $44.2 \%$ & $46.1 \%$ & $44.3 \%$ \\
Ages 60-64 & $5.6 \%$ & $7.5 \%$ & $6.9 \%$ & $6.3 \%$ & $5.6 \%$ & $7.5 \%$ \\
Married & $91.3 \%$ & $75.5 \%$ & $91.6 \%$ & $72.2 \%$ & $90.6 \%$ & $66.3 \%$ \\
Agriculture & $0.9 \%$ & $6.5 \%$ & $1.4 \%$ & $11.7 \%$ & $0.1 \%$ & $6.3 \%$ \\
Construction & $1.8 \%$ & $18.2 \%$ & $4.3 \%$ & $13.6 \%$ & $6.8 \%$ & $21.1 \%$ \\
Sample size & 2,684 & 432,399 & 418 & 30,171 & 1,825 & 78,016 \\
\hline
\end{tabular}

Notes: (1) The sample consists of the self-employed business owners ages 25-64. (2) UK includes England and Wales only. For UK 'Asian immigrants' group is defined by country of birth and self-reported ethnicity and does not include all persons born in Asia and residing in the UK. For example, does not include ethnic British born in India. 
Table 8

Log Net Busines Income Regressions

U.S. Census 2000

Explanatory Variables

(1)

(2)

Indian immigrant

0.4843

(0.0262)

0.1314

College graduate

$(0.0246)$

College gr

0.6223

(0.0041)

Female

$-0.7520$

(0.0041)

Ages 25-29

$-0.2540$

(0.0079)

Ages 45-59

0.0023

(0.0040)

Ages 60-64

$-0.1867$

(0.0074)

Married

0.1633

(0.0043)

Agirculture

$-0.6274$

(0.0083)

Construction

$-0.0545$

Region controls

(0.0052)

Mean of dependent variable

No

Yes

Sample size

10.14

10.14

534,044

534,044

Notes: (1) The sample consists of self-employed business owners (ages 25-64) who work 15 or more hours per week. (2) Additional controls include other Asian immigrant, Asian native, white immigrant, black native, black

immigrant, Latino native, Latino immigrant, Native American, other race, and multiple race dummies. (3) The left-out categories are white natives and ages 30-44. 
Table 9

Decompositions of Indian/Native-Born White Gaps in Business Performance

U.S. Census 2000, Canada Census 2001, and U.K. Census 2001

\begin{tabular}{lcccc} 
& U.S. & Canada & Canada & U.K. \\
\hline & Log Business & Log Business & & \\
Dependent variable & Income & Income & Employer & Employer \\
Indian mean & 10.65 & 10.07 & 0.4910 & 0.5360 \\
Native-born white mean & 10.17 & 10.01 & 0.4410 & 0.3710 \\
Indian/native-born white gap & 0.4781 & 0.0600 & 0.0500 & 0.1650 \\
Contributions from group & & & & \\
differences in: & & & & \\
Education & 0.2098 & 0.1250 & 0.0177 & 0.0026 \\
& $43.9 \%$ & & $35.4 \%$ & $1.6 \%$ \\
Female & 0.0405 & 0.0270 & 0.0056 & -0.0006 \\
& $8.5 \%$ & & $11.2 \%$ & $-0.4 \%$ \\
Age & 0.0072 & -0.0008 & -0.0002 & 0.0022 \\
& $1.5 \%$ & & $-0.4 \%$ & $1.3 \%$ \\
Marital status & 0.0258 & 0.0239 & 0.0235 & 0.0194 \\
& $5.4 \%$ & & $46.9 \%$ & $11.8 \%$ \\
Industrial sector & 0.0446 & 0.0438 & 0.0121 & 0.0204 \\
& $9.3 \%$ & & $24.3 \%$ & $12.4 \%$ \\
Region & 0.0265 & 0.0296 & 0.0095 & \\
All included variables & $5.5 \%$ & & $19.1 \%$ & \\
& 0.3544 & 0.2484 & 0.0683 & 0.0440 \\
\hline
\end{tabular}

Notes: (1) The samples and regression specifications are the same as those used in Tables 8,10 and 11.

(2) See text for more details on decomposition equations. 
Table 10

Log Net Busines Income and Employer Firm Regressions

Canada Census 2001

Log Business Income Employer Firm

\begin{tabular}{|c|c|c|c|c|}
\hline Explanatory Variables & $(1)$ & (2) & (3) & (4) \\
\hline Indian immigrant & $\begin{array}{c}0.0583 \\
(0.0526)\end{array}$ & $\begin{array}{l}-0.1855 \\
(0.0518)\end{array}$ & $\begin{array}{c}0.0510 \\
(0.0250)\end{array}$ & $\begin{array}{l}-0.0020 \\
(0.0250)\end{array}$ \\
\hline College graduate & & $\begin{array}{c}0.5081 \\
(0.0139)\end{array}$ & & $\begin{array}{c}0.0720 \\
(0.0060)\end{array}$ \\
\hline Female & & $\begin{array}{l}-0.5185 \\
(0.0130)\end{array}$ & & $\begin{array}{l}-0.1080 \\
(0.0060)\end{array}$ \\
\hline Ages 25-29 & & $\begin{array}{l}-0.2057 \\
(0.0265)\end{array}$ & & $\begin{array}{l}-0.0620 \\
(0.0120)\end{array}$ \\
\hline Ages 45-59 & & $\begin{array}{c}0.0056 \\
(0.0123)\end{array}$ & & $\begin{array}{c}0.0010 \\
(0.0060)\end{array}$ \\
\hline Ages 60-64 & & $\begin{array}{l}-0.1574 \\
(0.0271)\end{array}$ & & $\begin{array}{l}-0.0430 \\
(0.0110)\end{array}$ \\
\hline Married & & $\begin{array}{c}0.1234 \\
(0.0135)\end{array}$ & & $\begin{array}{c}0.1210 \\
(0.0060)\end{array}$ \\
\hline Agirculture & & $\begin{array}{l}-0.4192 \\
(0.0206)\end{array}$ & & $\begin{array}{l}-0.1340 \\
(0.0090)\end{array}$ \\
\hline Construction & & $\begin{array}{l}-0.0062 \\
(0.0165)\end{array}$ & & $\begin{array}{c}0.0180 \\
(0.0090)\end{array}$ \\
\hline Region controls & No & Yes & No & Yes \\
\hline Mean of dependent var & 9.9990 & 9.9990 & 0.45 & 0.45 \\
\hline Sample size & 33,676 & 33,676 & 33,676 & 33,676 \\
\hline
\end{tabular}


Table 11

Employer Firm Regressions

U.K. Census 2001

\begin{tabular}{lcc} 
Explanatory Variables & $(1)$ & $(2)$ \\
\hline Indian immigrant & 0.170 & 0.125 \\
College graduate & $(0.011)^{* *}$ & $(0.011)$ \\
& & 0.018 \\
Female & $(0.004)$ \\
Ages 25-29 & -0.021 \\
& $(0.004)$ \\
Ages 45-59 & -0.037 \\
& $0.007)$ \\
Ages 60-64 & -0.011 \\
& & $0.004)$ \\
Married & -0.052 \\
& & $0.007)$ \\
Agriculture & & 0.080 \\
& & $0.004)$ \\
Construction & -0.073 \\
& & $(0.007)$ \\
Mean of dependent variable & -0.111 \\
Sample size & & $(0.004)$ \\
\hline
\end{tabular}

Notes: (1) The sample consists of self-employed business owners (ages 25-64) who work 15 or more hours per week. (2) Additional controls include other Asian immigrant, Asian native, white immigrant, black native, black immigrant, Latino native, Latino immigrant, Native American, other race, and multiple race dummies. (3) The left-out categories are white natives and ages 30-44. 